\title{
Infiltration and Sediment Production Following Chemical Control of Sagebrush in New Mexico
}

\author{
JOHN F. BALLIETTE, KIRK C. MCDANIEL, AND M. KARL WOOD
}

Abstract

Terminal infiltration rates under sagebrush canopies were about 35\% higher than interspace areas at 3 study sites in northern New Mexico. Differences in infiltration rates among strata may largely be attributed to a greater amount of litter yield and basal cover, and 2 to 3 times higher percentage of organic carbon under the canopy of sagebrush compared to the interspace. Infiltration rates and sediment concentration of runoff within the canopy zone and interspace areas were not affected chemical control treatments. Total sediment production was about 29 to $41 \%$ higher under the canopy of tebuthiuron treated sagebrush compared to the canopy zone of untreated rangeland. However, these differences were not consistent and were significant at only 1 study site. Total sediment production was related primarily to a combination of soil texture, sagebrush canopy cover, and total vegetation production.

Authors are former graduate research assistant and associate professors, Department of Animal and Range Sciences, New Mexico State University, Las Cruces $\mathbf{8 8 0 0 1}$.

Received for publication as journal article no. 1143 from the New Mexico Agricultural Experiment Station.

Manuscript accepted 25 July 1985.
Sagebrush (Artemisia tridentata) is an aromatic, evergreen shrub growing on an estimated 2.2 million ha of rangeland in northern New Mexico and an additional 37 million ha in the western United States (Berry 1979). Approximately $70 \%$ of the sagebrush-dominated rangelands in New Mexico are degraded and produce less forage than their potential (McDaniel and Garrison 1982). Reasons often given to justify renovation of the sagebrush rangelands include the need to increase forage for wildlife and livestock, and to reduce soil degradation (Scifres 1980).

Herbicide applications are an accepted tool to improve sagebrush rangelands, but have not been widely used in New Mexico. Control of sagebrush with 2,4-D [(2,4-dichlorophenoxy) acetic acid] at rates of $2.2 \mathrm{~kg}$ acid equivalence/ha, while reported elsewhere as successful in killing sagebrush (Elwell and Cox 1950, Hull and Vaughan 1951, Hyder 1953, Evans et al. 1979, among others), has not been successfully employed in New Mexico (McDaniel and Balliette 1984). Three years of repeated spray trials with 2,4-D at 2.2. $\mathrm{kg}$ a.e./ha did not kill more than $50 \%$ of Wyoming (A.t. var. 
wyomenisis) or mountain (A.t. var. vaseyana) sagebrush in northern New Mexico (Balliette 1984).

Tebuthiuron (N-[5-(1,1-dimethylethyl)-1,3,4-thiadiazol-2-yl]-N,N'dimethylurea) at $0.56 \mathrm{~kg}$ active ingredient/ha offers significant promise for sagebrush control in New Mexico. Date of application or phenological stage of sagebrush growth does not limit tebuthiuron activity, and the herbicide usually kills more than $80 \%$ of the plants (McDaniel and Balliette 1984). Similar levels of sagebrush control following tebuthiuron treatments have been reported in Oregon and Wyoming (Britton and Sneva 1984, Whitson and Alley 1984).

Increased forage production is a primary reason to control sagebrush with herbicides. Reduction of soil erosion is often given as an additional benefit; however, little information exists for New Mexico rangelands about the impact of sagebrush control on infiltration rates and sediment production. Sagebrush rangelands in poor condition lose considerable amounts of soil by wind and water erosion (Rosa and Tigerman 1951, Tisdale et al. 1969, and Blackburn 1973). Management and control of sagebrush can increase cover and yield of herbaceous species and reverse the soil degradation that has occurred over the past century (Young et al. 1980).

Our primary objective was to determine the short-term impact on infiltration rates, sediment concentration of runoff, and total sediment production from sagebrush rangelands treated with herbicides. A secondary objective was to identify vegetation and soil characteristics related to these watershed parameters.

\section{Study Area}

Experiments were conducted at 3 locations in New Mexico's northern desert land resource area (USDA-SCS 1982) near Aztec, Bloomfield, and Gobernador, New Mexico. Average annual precipitation is $226 \mathrm{~mm}$ at Aztec, with yearly variations of from one-half to more than 2 times the average. Major precipitation occurs between July and October from scattered, localized, and intense thunderstorms. Temperatures vary from highs that commonly exceed $40.5^{\circ} \mathrm{C}$ during June or July, to lows of $-20.5^{\circ} \mathrm{C}$ or below in December or January. Soils of the resource area were formed from alluvial sediments or sedimentary rock. The geomorphology is typically that of moderate canyon dissection, broad valleys, and gentle sloping plateaus and mesas.

The Bloomfield and Aztec sites were established on deep and well-drained Doak loam soil (fine-loamy, mixed, mesic, Typic Haplargid). Soil samples collected from a core to $10 \mathrm{~cm}$ at Bloomfield contained $86 \%$ sand, $12 \%$ silt and $2 \%$ clay, with $1.3 \%$ organic carbon and a pH of 7.5. Soil at Aztec contained $72 \%$ sand, $24 \%$ silt and $4 \%$ clay, with $1.6 \%$ organic carbon and a $7.0 \mathrm{pH}$. Herbaceous vegetation at Aztec included squirreltail (Sitanion hystrix), galleta (Hilaria jamesii), cheatgrass (Bromus tectorum), six-weeks fescue (Vulpia octoflora), broom snakeweed (Gutierrezia sarothrae) and several annual broadleaf species. The Bloomfield site, included, in addition to the above herbaceous species, blue grama (Bouteloua gracilis), sand dropseed (Sporobolus cryptandrus) and ring muhly (Muhlenbergia torreyii). The average slope at both areas was 1 to $3 \%$ and elevation averaged $1,850 \mathrm{~m}$.

The Gobernador site was on a Penistaja loam (fine-loamy, mixed mesic, Ustollic Haplargid) that is a well-drained soil with an effective rooting depth of $150 \mathrm{~cm}$ or more. Soils contained $74 \%$ sand, $23 \%$ silt and $3 \%$ clay, with $2.7 \%$ organic carbon and a $\mathrm{pH}$ of 6.9. Herbaceous vegetation included galleta, blue grama, sand dropseed, squirreltail, cheatgrass, six-weeks fescue and various annual broadleaf species. Slope at the site ranged from 2 to $5 \%$ and elevation was about $2,000 \mathrm{~m}$.

The 3 study areas supported a uniform stand of Wyoming sagebrush as the sole dominant woody species. Sagebrush height ranged from $0.1 \mathrm{~m}$ to $1.5 \mathrm{~m}$, not including seedlings. Sagebrush density and canopy cover averaged 22,977 plants/ ha and $17.4 \%$ cover at Aztec, 33,300 plants/ha and $19.0 \%$ cover at Bloomfield,
Table 1. Mean terminal infiltration rates $(\mathrm{cm} / \mathrm{hr})$ for canopy-interspace areas as infuenced by sagebrush control treatments, from three study areas in New Mexico in 1982 and 1983.

\begin{tabular}{|c|c|c|c|c|}
\hline \multirow[b]{2}{*}{ Site $^{1}$} & \multirow[b]{2}{*}{ Treatment } & \multirow[b]{2}{*}{ Strata } & \multicolumn{2}{|c|}{ Terminal Infiltration ${ }^{2}$} \\
\hline & & & 1982 & 1983 \\
\hline \multirow[t]{2}{*}{$\begin{array}{l}\text { Bloomfield } \\
(4.2 \mathrm{a}, 4.1 \mathrm{a})\end{array}$} & $\begin{array}{l}\text { 2,4-D } \\
(4.0 \mathrm{a}, 4.1 \mathrm{a})\end{array}$ & $\begin{array}{l}\text { Canopy } \\
\text { Interspace }\end{array}$ & $\begin{array}{r}4.6^{2} \\
3.4 a\end{array}$ & $\begin{array}{l}4.9 \mathrm{~b} \\
3.2 \mathrm{a}\end{array}$ \\
\hline & $\begin{array}{l}\text { Tebuthiuron } \\
\text { (4.4a, } 4.1 \mathrm{a}) \\
\text { Control } \\
(4.3 \mathrm{a}, 4.1 \mathrm{a})\end{array}$ & $\begin{array}{l}\text { Canopy } \\
\text { Interspace } \\
\text { Canopy } \\
\text { Interspace }\end{array}$ & $\begin{array}{l}5.2 \mathrm{bc} \\
3.7 \mathrm{a} \\
5.0 \mathrm{~b} \\
3.5 \mathrm{a}\end{array}$ & $\begin{array}{l}5.0 \mathrm{~b} \\
3.2 \mathrm{a} \\
5.3 \mathrm{~b} \\
2.8 \mathrm{a}\end{array}$ \\
\hline \multirow[t]{3}{*}{$\begin{array}{l}\text { Gobernador } \\
(4.2 a, 3.9 a)\end{array}$} & $\begin{array}{l}2,4-\mathrm{D} \\
(4.2 \mathrm{a}, 3.7 \mathrm{a})\end{array}$ & $\begin{array}{l}\text { Canopy } \\
\text { Interspace }\end{array}$ & $\begin{array}{l}4.9 \mathrm{~b} \\
3.6 \mathrm{a}\end{array}$ & $\begin{array}{l}4.4 \mathrm{~b} \\
2.9 \mathrm{a}\end{array}$ \\
\hline & $\begin{array}{l}\text { Tebuthiuron } \\
\text { (3.8a, 3.8a) }\end{array}$ & $\begin{array}{l}\text { Canopy } \\
\text { Interspace }\end{array}$ & $\begin{array}{l}4.3 \mathrm{ab} \\
3.2 \mathrm{a}\end{array}$ & $\begin{array}{l}4.4 \mathrm{~b} \\
3.2 \mathrm{a}\end{array}$ \\
\hline & $\begin{array}{l}\text { Control } \\
(4.7 \mathrm{a}, 4.2 \mathrm{a})\end{array}$ & $\begin{array}{l}\text { Canopy } \\
\text { Interspace }\end{array}$ & $\begin{array}{l}5.0 \mathrm{~b} \\
4.3 \mathrm{ab}\end{array}$ & $\begin{array}{l}4.9 \mathrm{~b} \\
3.4 \mathrm{a}\end{array}$ \\
\hline \multirow[t]{3}{*}{$\begin{array}{l}\text { Aztec } \\
(4.3 \mathrm{a}, 4.6 \mathrm{~b})\end{array}$} & $\begin{array}{l}2,4-D \\
(4.1 a, 4.6 a)\end{array}$ & $\begin{array}{l}\text { Canopy } \\
\text { Interspace }\end{array}$ & $\begin{array}{l}5.2 \mathrm{bc} \\
3.0 \mathrm{a}\end{array}$ & $\begin{array}{l}5.5 \mathrm{~b} \\
3.6 \mathrm{a}\end{array}$ \\
\hline & $\begin{array}{l}\text { Tebuthiuron } \\
\text { (4.5a, 4.5a) }\end{array}$ & $\begin{array}{l}\text { Canopy } \\
\text { Interspace }\end{array}$ & $\begin{array}{l}5.7 \mathrm{c} \\
3.4 \mathrm{a}\end{array}$ & $\begin{array}{l}5.7 \mathrm{~b} \\
3.4 \mathrm{a}\end{array}$ \\
\hline & $\begin{array}{l}\text { Control } \\
(4.3 a, 4.6 a)\end{array}$ & $\begin{array}{l}\text { Canopy } \\
\text { Interspace }\end{array}$ & $\begin{array}{l}5.5 \mathrm{c} \\
3.0 \mathrm{a}\end{array}$ & $\begin{array}{l}5.7 \mathrm{~b} \\
3.5 \mathrm{a}\end{array}$ \\
\hline
\end{tabular}

'Means under a site and treatment correspond to data collected in 1982 and 1983 , respectively.

${ }_{2}^{2}$ Means under a column heading and within a site following by the same letter are not significantly different at the 0.05 probablity level.

and 30,970 plants/ha and $14.9 \%$ cover at Gobernador.

\section{Methods}

Infiltration rates, sediment concentration of runoff, total sediment production, and soil and vegetation characteristics were measured in June 1982 and 1983 on areas treated with herbicides in May 1981 (McDaniel and Balliette 1984). Treatments replicated twice in a randomized complete block design included: (1) no treatment, (2) hand broadcast application of tebuthiuron $20 \%$ pellets at a $0.56 \mathrm{~kg} /$ ha rate, and (3) ground spraying of 2,4-D ester at $2.2 \mathrm{~kg} / \mathrm{ha}$. Within each 0.15 -ha plot where a sagebrush control treatment was applied, an equal number of measurements were taken from shrub canopy (coppice dunes) or interspace areas. The same criteria defined by Blackburn and Skau (1974) to describe the shrub canopy zone and interspace areas were used. Each of these strata was sampled with 3 randomly located infiltration plots per replicated herbicide treatment (i.e., 6 total infiltrometer plots per herbicide treatment per year).

A mobile drip infiltrometer (Blackburn et al. 1974) simulated rainfall at a rate of $10.7 \mathrm{~cm} / \mathrm{hr}$ for 45 minutes in square $1-\mathrm{m}^{2}$ plots. Average drop size was $2.5 \mathrm{~mm}$ diameter. Velocity of raindrops reaching the soil surface was $70 \%$ of natural rainfall. A large rainstorm event was used in order to ensure runoff. Rainfall of this intensity is similar to a short-duration, convectional thunderstorm that typically occurs in August or September in this region (USDA-SCS 1982). Before the simulated rainfall, each plot was pre-wetted to about a $15-\mathrm{cm}$ depth at a constant rate $(1.91 / \mathrm{hr})$ and duration $(1 \mathrm{hr})$. Saturated plots were then covered with plastic and sampled 24 hours later when soils were assumed to be near field capacity. Infiltration rates were determined by subtracting runoff volume from the simulated rainfall at 5-minute intervals and converting to $\mathrm{cm} / \mathrm{hr}$. Terminal infiltration was determined by averag- 
ing the 35, 40, and 45-minute time interval infiltration rates. Total runoff collected from a plot was thoroughly agitated and a oneliter subsample was taken. This subsample was filtered, ovendried, and converted to sediment concentration $(\mathrm{g} / \mathrm{l})$ and total sediment loss $(\mathrm{kg} / \mathrm{ha} / \mathrm{hr})$.

Soil characteristics measured for each plot included bulk density at 2 depths $(0-5 \mathrm{~cm}$ and $5-10 \mathrm{~cm})$ using a bulk density core. Surface soil texture was determined using the Bouyoucos hydrometer method (Bouyoucos 1962). Soil organic carbon was determined using acid dichromate oxidation (Blake 1965). A microrelief meter was used to determine surface roughness (Kincaid and Williams 1966). The meter, consisting of 20 pins spaced at $5-\mathrm{cm}$ intervals, was placed across each $1 \mathrm{~m}^{2}$ plot 3 times. Differences in pin height were measured to the nearest $\mathrm{cm}$ and the average standard deviation was compared between herbicide treatments.

Vegetative characteristics measured for each plot included basal cover of vegetation, litter, and bare ground. Estimates of basal cover were obtained by using the pins of the microrelief meter. Cover values for grass, forbs, shrubs, litter, and bare ground were converted to percentages. After taking infiltrometer data, standing live and dead vegetation were clipped to ground level in the $1-\mathrm{m}^{2}$ plots and divided into classes of grass, forb, shrub, and litter. These materials were oven-dried, weighed, and converted to $\mathrm{kg} / \mathrm{ha}$. Visual estimates were made of the percentage of sagebrush canopy cover and percentage of live canopy reduction in each sampling area.

All data, except sediment concentration of runoff and total sediment production (Blackburn 1984), were assumed to be normally distributed and subjected to analysis of variance. Logarithmic transformations were made on the sediment concentration data. Data were analyzed separately by year, and Duncan's multiple range test was used to separate means where significant $F$ ratios

Table 2. Mean and standard deviation (in parentheses) values for soil and vegetative characteristics determined from untreated rangeland at 3 study sites in northern New Mexico, 1983-84.

\begin{tabular}{|c|c|c|c|c|c|c|c|c|}
\hline & \multicolumn{8}{|c|}{ Bloomfield } \\
\hline & \multicolumn{4}{|c|}{ Canopy } & \multicolumn{4}{|c|}{ Interspace } \\
\hline & \multicolumn{2}{|c|}{1982} & \multicolumn{2}{|c|}{1983} & \multicolumn{2}{|c|}{1982} & \multicolumn{2}{|c|}{1983} \\
\hline & $\overline{\bar{x}}$ & (s) & $\overline{\bar{x}}$ & (s) & $\vec{x}$ & (s) & $\bar{x}$ & (s) \\
\hline \multicolumn{9}{|l|}{$\begin{array}{l}\text { Soil Characteristics } \\
\text { Bulk density }(\mathrm{g} / \mathrm{cc})\end{array}$} \\
\hline $0-5 \mathrm{~cm}$ & 1.4 & $(0.1)$ & 1.3 & $(0.1)$ & 1.4 & $(0.1)$ & 1.3 & (0.2) \\
\hline $5-10 \mathrm{~cm}$ & 1.4 & (0.1) & 1.3 & (0.1) & 1.4 & $(0.1)$ & 1.4 & $(0.1)$ \\
\hline \multicolumn{9}{|l|}{ Texture (\%): } \\
\hline Sand & 90.0 & (2.2) & 87.2 & (1.3) & 87.0 & (3.1) & 81.3 & (3.5) \\
\hline Silt & 8.0 & (2.0) & 10.8 & (1.2) & 11.0 & (2.3) & 15.8 & (3.0) \\
\hline Clay & 2.0 & (0.8) & 2.0 & $(0.6)$ & 2.0 & $(0.8)$ & 2.8 & $(0.8)$ \\
\hline Organic carbon (\%) & 1.7 & $(0.4)$ & 1.6 & $(0.5)$ & 0.9 & $(0.3)$ & 1.0 & $(0.2)$ \\
\hline $\begin{array}{l}\text { Microtopography } \\
\text { (cm) }\end{array}$ & \multicolumn{7}{|c|}{ Microtopography } & $(0.2)$ \\
\hline \multicolumn{9}{|c|}{ Vegetative Characteristics } \\
\hline Herbaceous & 18.0 & $(10.0)$ & 20.9 & $(14.0)$ & 23.0 & $(8.9)$ & 36.4 & (20.3) \\
\hline Litter & 96.0 & (46.0) & 190.5 & $(80.0)$ & 86.0 & (62.0) & 126.2 & (62.4) \\
\hline \multicolumn{9}{|l|}{ Basal Cover (\%): } \\
\hline Herbaceous & 1.0 & $(1.0)$ & 3.8 & $(4.2)$ & 2.3 & $(1.0)$ & 2.9 & (2.4) \\
\hline Litter & 31.0 & $(10.0$ & 29.8 & (10.9) & 16.0 & (4.0) & 11.7 & (8.1) \\
\hline \multirow{6}{*}{$\begin{array}{l}\text { Shrub Canopy } \\
\text { (Cover \%) }\end{array}$} & & & & & & & & \\
\hline & 50.0 & $(12.0)$ & 50.8 & (26.7) & 0 & 0 & 0 & 0 \\
\hline & \multicolumn{8}{|c|}{ Gobernador } \\
\hline & \multicolumn{4}{|c|}{ Canopy } & \multicolumn{4}{|c|}{ Interspace } \\
\hline & \multicolumn{2}{|c|}{1982} & \multicolumn{2}{|c|}{1983} & \multicolumn{2}{|c|}{1982} & \multicolumn{2}{|c|}{1983} \\
\hline & $\overline{\bar{x}}$ & (s) & $\overline{\bar{x}}$ & (s) & $\overline{\bar{x}}$ & (s) & $\bar{x}$ & (s) \\
\hline \multicolumn{9}{|l|}{$\begin{array}{l}\text { Soil Characteristics } \\
\text { Bulk density }(\mathrm{g} / \mathrm{cc})\end{array}$} \\
\hline $0-5 \mathrm{~cm}$ & 1.4 & $(0.1)$ & 1.0 & $(0.1)$ & 1.4 & $(0.1)$ & 1.3 & (0.1) \\
\hline $5-10$ & 1.4 & (0.1) & 1.3 & $(0.1)$ & 1.4 & (0.1) & 1.3 & (0.1) \\
\hline \multicolumn{9}{|l|}{ Texture (\%): } \\
\hline Sand & 75.0 & $(1.2)$ & 75.0 & $(0.6)$ & 75.0 & $(0.9)$ & 71.7 & (1.2) \\
\hline Silt & 22.0 & (2.0) & 23.2 & $(0.7)$ & 22.0 & (1.2) & 25.3 & $(0.8)$ \\
\hline Clay & 3.0 & (1.0) & 1.8 & (0.4) & 3.0 & (1.0) & 3.0 & (0.6) \\
\hline \multirow{2}{*}{$\begin{array}{l}\text { Organic carbon (\%) } \\
\text { Microtopography } \\
\text { (cm) }\end{array}$} & $\begin{array}{l}3.0 \\
1.3\end{array}$ & $(0.8)$ & 2.8 & $(0.7)$ & 0.6 & $(0.2)$ & 0.9 & $(0.1)$ \\
\hline & 2.7 & $(0.9)$ & 1.8 & $(0.6)$ & 1.7 & $(1.1)$ & 1.3 & $(0.3)$ \\
\hline \multicolumn{9}{|c|}{ Vegetative Characteristics } \\
\hline Yield $(\mathrm{kg} / \mathrm{ha})$ : & & & & & & & & \\
\hline $\begin{array}{l}\text { Yeld (Kg/ ha): } \\
\text { Herbaceous }\end{array}$ & 19.0 & $(7.3)$ & 51.8 & $(13.0)$ & 25.0 & (7.0) & 54.5 & (26.0) \\
\hline Litter & 156.0 & $(63.5)$ & 353.4 & (103.3) & 110.0 & $(165.0)$ & 112.5 & (84.3) \\
\hline Basal Cover (\%): & & & & & & & & \\
\hline Herbaceous & 4.0 & $(4.0)$ & 7.1 & (4.0) & 6.7 & (1.1) & 3.0 & (2.0) \\
\hline Litter & 36.0 & $(8.9)$ & 51.7 & $(9.3)$ & 26.0 & (5.1) & 18.2 & $(8.1)$ \\
\hline $\begin{array}{l}\text { Chwinh ranans, } \\
\text { Cover (\%) }\end{array}$ & 45.0 & $(17.0)$ & 34.2 & (9.2) & 0 & 0 & 0 & 0 \\
\hline
\end{tabular}




\begin{tabular}{|c|c|c|c|c|c|c|c|c|}
\hline & \multicolumn{8}{|c|}{ Aztec } \\
\hline & \multicolumn{4}{|c|}{ Canopy } & \multicolumn{4}{|c|}{ Interspace } \\
\hline & \multicolumn{2}{|c|}{1982} & \multicolumn{2}{|c|}{1983} & \multicolumn{2}{|c|}{1982} & \multicolumn{2}{|c|}{1983} \\
\hline & $\overline{\bar{x}}$ & (s) & $\overline{\bar{x}}$ & (s) & $\overline{\bar{x}}$ & (s) & $\bar{x}$ & (s) \\
\hline \multicolumn{9}{|l|}{ Soil Characteristics } \\
\hline $\begin{array}{l}0-5 \mathrm{~cm} \\
5-10 \mathrm{~cm}\end{array}$ & $\begin{array}{l}1.2 \\
1.3\end{array}$ & $\begin{array}{l}(0.1) \\
(0.1)\end{array}$ & $\begin{array}{l}1.0 \\
1.1\end{array}$ & $\begin{array}{l}(0.1) \\
(0.1)\end{array}$ & $\begin{array}{l}1.3 \\
1.3\end{array}$ & $\begin{array}{l}(0.0) \\
(0.1)\end{array}$ & $\begin{array}{l}1.2 \\
1.2\end{array}$ & $\begin{array}{l}(0.1) \\
(0.1)\end{array}$ \\
\hline \multicolumn{9}{|l|}{ Texture (\%): } \\
\hline Sand & 74.0 & $(0.8)$ & 72.7 & $(0.5)$ & 72.0 & $(2.0)$ & 69.3 & (2.4) \\
\hline Silt & 22.0 & (1.9) & 24.5 & $(0.6)$ & 22.0 & $(1.2)$ & 25.8 & $(2.1)$ \\
\hline Clay & 3.0 & (1.0) & 2.8 & (0.4) & 6.0 & $(2.0)$ & 4.8 & $(0.8)$ \\
\hline Organic carbon (\%) & 2.5 & $(0.8)$ & 2.7 & $(0.6)$ & 0.7 & $(0.1)$ & 0.6 & $(0.3)$ \\
\hline $\begin{array}{l}\text { Microtopography } \\
\text { (cm) }\end{array}$ & 2.1 & $(1.0)$ & 2.0 & $(0.4)$ & 0.8 & $(0.3)$ & 1.1 & $(0.2)$ \\
\hline \multicolumn{2}{|l|}{ Yield (kg/ha) } & & & & & & & \\
\hline $\begin{array}{l}\text { Herbaceous } \\
\text { Litter }\end{array}$ & $\begin{array}{r}17.2 \\
270.0\end{array}$ & $\begin{array}{r}(12.0) \\
(361.0)\end{array}$ & $\begin{array}{r}18.8 \\
314.9\end{array}$ & $\begin{array}{r}(6.0) \\
(189.5)\end{array}$ & $\begin{array}{r}6.0 \\
82.0\end{array}$ & $\begin{array}{r}(5.0) \\
(72.0)\end{array}$ & $\begin{array}{r}20.7 \\
243.5\end{array}$ & $\begin{array}{r}(12.6) \\
(225.2)\end{array}$ \\
\hline \multicolumn{9}{|l|}{ Basal Cover (\%): } \\
\hline Herbaceous & 3.0 & $(2.0)$ & 0.3 & $(0.2)$ & 2.0 & $(5.0)$ & 1.7 & (2.3) \\
\hline Litter & 35.0 & $(14.0)$ & 55.5 & (21.3) & 4.0 & $(5.0)$ & 12.0 & $(9.0)$ \\
\hline \multicolumn{9}{|l|}{ Shrub Canopy } \\
\hline Cover $(\%)$ & 60.0 & $(14.0)$ & 57.5 & (26.7) & 0 & 0 & $\mathbf{0}$ & 0 \\
\hline
\end{tabular}

were obtained ( $P \leq .05$ ) (Steel and Torrie 1960). Regression analyses by year were used to determine the influence of soil and vegetative characteristics on terminal infiltration, sediment concentration of runoff, and total sediment production.

\section{Results and Discussion}

\section{Infiltration}

Average terminal infiltration rates were not significantly different between sites in 1982, but were slightly higher at Aztec in 1983 compared to the Bloomfield and Gobernador study areas (Table 1). Terminal infiltration under the sagebrush canopy was consistently higher at the Aztec site than at the other 2 areas, whereas infiltration rates in the interspace were similar among the 3 sites.

Terminal infiltration rates were higher under the sagebrush canopy than in the interspace regardless of site or treatment (Table 1). Infiltration rates in the interspace were about $35 \%$ less than in the canopy zone. These data agree with Blackburn (1975) when he reported that sagebrush canopy zones have a higher infiltration rate, sometimes 3 to 4 times greater, than interspace areas. In a similar study with mesquite (Prosopis glandulosa), Brock et al. (1982) reported infiltration to be about twice as high under the canopy than in the interspace. Brock et al. (1982) attributed differences in infiltration rates among strata to be largely the result of the area under the canopy having a greater amount of litter and vegetation basal cover, a higher percentage of sand particles, 2 to 3 times higher percentage of organic carbon, and lower soil bulk density. In this study, litter yield and basal cover, microtopography (microrelief standard deviation), and percentage organic carbon were consistently higher under sagebrush than in the interspace (Table 2). There was also a trend of lower soil bulk density and a higher percentage of sand particles under the canopy compared to the interspace, but these differences were not always consistent.

Infiltration rates averaged across sites and vegetation zones were not significantly different among treatments for either year sampled (Table 1). Soil characteristics remained unchanged from 1982 to 1983 and were not influenced by herbicide applications (data not shown). Leaf cover of sagebrush was reduced by $100 \%$ in the completely defoliated tebuthiuron treatments, and about 50 to $60 \%$ in the partially defoliated $2,4-\mathrm{D}$ spray. However, dead standing sagebrush branches and stems remained in both herbicide treatments providing ground cover. Herbaceous vegetation yield and basal cover were generally highest in the tebuthiuron treatment, intermediate in the 2,4-D spray, and lowest in the control, especially the third growing season after treatment (1983) (data not shown). However these differences were not consistent across study areas and no significant differences were found.

Regression analyses on data combined by site, strata, and treatment for a particular year indicated the primary factors positively correlated with terminal infiltration rates were sagebrush canopy cover and weight, litter cover and weight, total basal cover, soil organic carbon, and microtopography (Table 3). Infiltration rate was negatively related to soil bulk density in 1983, and clay content in the soil both years. The effects of these soil and vegetative variables upon infiltration rate are consistent with other watershed studies conducted in the sagebrush ecosystem (Blackburn 1984).

\section{Sediment Concentration of Runofi}

Sediment concentration, measured from the runoff of each of the plots, was lower at the Bloomfield site than at the Aztec or Gobernador sites (Table 4). A combination of soil characteristics can influence sediment concentration, but suspended materials in the runoff are primarily silt and clay particles (Satterlund 1972). The higher concentrations of sediments in the runoff at the Aztec and Gobernador sites compared to the Bloomfield area may be attributed to a greater percentage of fine materials (primarily silt) at the soil surface (Table 2). Percentage of sand (negative correlation) and silt (positive correlation) were highly related to sediment concentration (Table 3 ). The unexpectedly high percentage of sand under the canopy may be partially due to aeolian deposition, in addition to losses of silt and clay particles in the runoff (Melton 1940). A lower average soil bulk density at Aztec and Governador also may have added to increased sediment concentrations by providing a less stable surface when exposed to the same amount of runoff as the Bloomfield site. Bulk density at both depths $(0-5 \mathrm{~cm}$ and $5-10 \mathrm{~cm}$ ) were negatively correlated to sediment concentration.

Sediment concentrations of runoff were not significantly different between herbicide treatments within a study site or when sites were combined (Table 4). An exception was a lower amount of sediment concentration in the 2,4-D spray compared to the other brush control treatments at the Bloomfield site. A nonsignificant trend of higher sediment concentration of runoff under the canopy zone of tebuthiuron treatments and a lower concentration within the control and 2,4-D spray canopy zones was apparent, especially the third growing season after brush control at Bloomfield and 
Table 3. Simple linear correlation coefficients $(r)$ between watershed parameters and selected soil and vegetative characteristics from three study sites 12 and 24 months after herbicide treatment in May 1981.

\begin{tabular}{|c|c|c|c|c|c|c|}
\hline & \multicolumn{2}{|c|}{$\begin{array}{c}\text { Terminal Infiltration } \\
(\mathrm{cm} / \mathrm{hr})\end{array}$} & \multicolumn{2}{|c|}{$\begin{array}{l}\text { Sediment Concentration } \\
(\mathrm{g} / \mathrm{l})\end{array}$} & \multicolumn{2}{|c|}{$\begin{array}{c}\text { Sediment Production } \\
(\mathrm{kg} / \mathrm{ha} / \mathrm{hr})\end{array}$} \\
\hline & 1982 & 1983 & 1982 & 1983 & 1982 & 1983 \\
\hline \multirow{2}{*}{\multicolumn{7}{|c|}{$\begin{array}{l}\text { Soil Characteristics } \\
\text { Bulk Density }(\mathrm{g} / \mathrm{cc}): 0-5 \mathrm{~cm}\end{array}$}} \\
\hline & $\neq 1$ & -.63 & -.28 & * & * & * \\
\hline $5-10 \mathrm{~cm}$ & $*$ & -.31 & -.23 & -.23 & -.22 & -.31 \\
\hline Texture (\%) sand & $*$ & $*$ & -.25 & -.24 & -.24 & -.28 \\
\hline silt & * & * & .30 & .25 & .23 & .28 \\
\hline clay & -.30 & -.46 & $*$ & 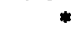 & .19 & .38 \\
\hline Organic Carbon (\%) & .60 & .57 & .31 & * & $*$ & -.24 \\
\hline Microrelief Standard & & & & & & \\
\hline Deviation (cm) & .40 & .49 & .20 & * & $*$ & -.34 \\
\hline \multicolumn{7}{|l|}{ Vegetative Characteristics } \\
\hline Production (kg/ha): grass & * & -.29 & * & * & * & * \\
\hline forb & $*$ & $*$ & * & * & * & $*$ \\
\hline shrub & .78 & .58 & .33 & * & -.22 & * \\
\hline total vegetation & .78 & .50 & .33 & * & -.22 & -.23 \\
\hline litter & .52 & .70 & .20 & * & $*$ & -.24 \\
\hline Relative Basal Cover (\%); grass & .21 & * & * & $*$ & $*$ & \\
\hline forb & * & * & $*$ & * & $*$ & $*$ \\
\hline litter & .58 & .53 & .22 & * & $*$ & -.36 \\
\hline total basal cover & .60 & .59 & .25 & * & -.18 & -.38 \\
\hline Sagebrush Canopy Cover $(\%)$ & .77 & .77 & .19 & * & -.29 & -.36 \\
\hline
\end{tabular}

Correlation coefficients were significant at the $99 \%$ or greater level. Values with an asterisk were not significant.

Gobernador. Greater plant biomass and ground cover have been concluded to protect areas from erosion and the sagebrush canopy does protect the soil surface by reducing the impact of raindrops (Blackburn 1973, Gifford and Hawkins 1976, Dixon 1978, Dunne and Leopold 1970). We believe longer-term research is needed to

\section{Table 4. Mean sediment concentration of runoff $(\mathrm{g} / \mathrm{l})$ canopy-interspace areas as influenced by sagebrush control treatments, from three study areas in New Mexico in 1982 and 1983.}

\begin{tabular}{|c|c|c|c|c|}
\hline \multirow[b]{2}{*}{ Site $^{1}$} & \multirow[b]{2}{*}{ Treatment } & \multirow[b]{2}{*}{ Strata } & \multicolumn{2}{|c|}{ Sediment Concentration $^{2}$} \\
\hline & & & 1982 & 1983 \\
\hline \multirow{4}{*}{$\begin{array}{l}\text { Bloomfield } \\
(1.9 \mathrm{a}, 3.7 \mathrm{c})\end{array}$} & & & & - \\
\hline & $\begin{array}{l}2,4-\mathrm{D} \\
(1.3 \mathrm{a}, 1.7 \mathrm{a})\end{array}$ & $\begin{array}{l}\text { Canopy } \\
\text { Interspace }\end{array}$ & $\begin{array}{l}1.1 \mathrm{a} \\
1.5 \mathrm{a}\end{array}$ & $\begin{array}{l}1.6 \mathrm{a} \\
1.9 \mathrm{a}\end{array}$ \\
\hline & $\begin{array}{l}\text { Tebuthiuron } \\
(2.0 \mathrm{a}, 4.9 \mathrm{~b})\end{array}$ & $\begin{array}{l}\text { Canopy } \\
\text { Interspace }\end{array}$ & $\begin{array}{l}2.6 \mathrm{a} \\
1.5 \mathrm{a}\end{array}$ & $\begin{array}{l}5.7 \mathrm{~b} \\
4.1 \mathrm{a}\end{array}$ \\
\hline & $\begin{array}{l}\text { Control } \\
(2.3 a, 4.4 b)\end{array}$ & $\begin{array}{l}\text { Canopy } \\
\text { Interspace }\end{array}$ & $\begin{array}{l}1.9 \mathrm{a} \\
2.6 \mathrm{a}\end{array}$ & $\begin{array}{l}4.9 \mathrm{ab} \\
3.8 \mathrm{a}\end{array}$ \\
\hline \multirow[t]{3}{*}{$\begin{array}{l}\text { Gobernador } \\
(2.8 b, 5.1 d)\end{array}$} & $\begin{array}{l}2,4-\mathrm{D} \\
(1.9 \mathrm{a}, 4.7 \mathrm{~b})\end{array}$ & $\begin{array}{l}\text { Canopy } \\
\text { Interspace }\end{array}$ & $\begin{array}{l}2.1 \mathrm{a} \\
1.8 \mathrm{a}\end{array}$ & $\begin{array}{l}5.6 \mathrm{~b} \\
3.8 \mathrm{a}\end{array}$ \\
\hline & $\begin{array}{l}\text { Tebuthiuron } \\
(3.6 \mathrm{ab}, 6.5 \mathrm{~b})\end{array}$ & $\begin{array}{l}\text { Canopy } \\
\text { Interspace }\end{array}$ & $\begin{array}{l}4.4 \mathrm{~b} \\
2.8 \mathrm{a}\end{array}$ & $\begin{array}{l}7.6 c \\
5.3 b\end{array}$ \\
\hline & $\begin{array}{l}\text { Control } \\
(2.8 \mathrm{a}, 4.0 \mathrm{~b})\end{array}$ & $\begin{array}{l}\text { Canopy } \\
\text { Interspace }\end{array}$ & $\begin{array}{l}2.6 a \\
2.9 a\end{array}$ & $\begin{array}{l}3.9 \mathrm{a} \\
4.2 \mathrm{a}\end{array}$ \\
\hline \multirow[t]{3}{*}{$\begin{array}{l}\text { Aztec } \\
(3.2 b, 8.4 d)\end{array}$} & $\begin{array}{l}2,4-D \\
(3.1 a, 8.2 c)\end{array}$ & $\begin{array}{l}\text { Canopy } \\
\text { Interspace }\end{array}$ & $\begin{array}{l}4.2 \mathrm{ab} \\
2.1 \mathrm{a}\end{array}$ & $\begin{array}{l}8.7 a b \\
7.6 a\end{array}$ \\
\hline & $\begin{array}{l}\text { Tebuthiuron } \\
(3.3 \mathrm{a}, 9.2 \mathrm{c})\end{array}$ & $\begin{array}{l}\text { Canopy } \\
\text { Interspace }\end{array}$ & $\begin{array}{l}3.4 \mathrm{a} \\
3.3 \mathrm{a}\end{array}$ & $\begin{array}{l}8.6 \mathrm{ab} \\
9.8 \mathrm{~b}\end{array}$ \\
\hline & $\begin{array}{l}\text { Control } \\
(3.1 \mathrm{a}, 7.8 \mathrm{c})\end{array}$ & $\begin{array}{l}\text { Canopy } \\
\text { Interspace }\end{array}$ & $\begin{array}{l}4.3 a \\
1.9 a\end{array}$ & $\begin{array}{l}6.7 \mathrm{ab} \\
8.9 \mathrm{ab}\end{array}$ \\
\hline
\end{tabular}

'Means under site and treatment correspond to data collected in 1982 and 1983 . respectively.

${ }^{2}$ Means under a column heading and within a study site followed by the same letter are not significantly different at the 0.05 probability level. determine if sediments actually increase from the canopy area of completely defoliated sagebrush compared to untreated rangeland.

\section{Total Sediment Production}

Differences in total sediment production between sites when strata and treatments were combined could be, as expected, largely attributed to the same soil characteristics used to explain differences in sediment concentration of runoff. Bulk density and percentage of sand were negatively correlated to sediment production (Tablc 5). These 2 soil characteristics were higher at the Bloomfield site, which had the lowest total sediment production of the 3 study areas (Tables 2 and 5). Percentages of silt and clay, which were positively correlated to sediment production, were highest at the Aztec and Gobernador sites and contributed a high amount of erosion compared to the Bloomfield site.

Total sediment production was 30 to $41 \%$ higher from the interspace than from canopy when measurements from all sites and treatments were combined for 1982 and 1983, respectively (Table 5). Sagebrush canopy cover and total vegetative production and basal cover showed negative and significant correlations to total sediment production and appear to be primary factors influencing differences between the strata (Table 5). However, soil characteristics (silt and clay, positive correlation; sand, bulk density, organic carbon (1983 only), and microrelief standard deviation (1983 only), negative correlation), also were highly correlated to sediment production and were equally important in explaining differences.

There was a significant interaction of sagebrush control treatments with strata on total sediment production for both measured years. There was also an interaction for sediment loss between brush control treatments and study sites (Table 5). It was hypothesized that sediment production would be accelerated by the complete defoliation of sagebrush by tebuthiuron. In general, sediment production was higher in the canopy of tebuthiuron treated areas and was less in the canopy of untreated rangeland. Surprisingly, sediment production in the interspace area of tebuthiuron treated plots was also generally higher than untreated, interspace areas. However, these differences were not consistent and were significant at only I study site.

In general, our research indicates herbicide treatment alone will not change watershed values in the short-term. Our data suggest 
Table 5. Mean total sediment production ( $\mathrm{kg} / \mathrm{ha} / \mathrm{hr}$ ) for canopy-interspace areas as influenced by sagebrush control treatments, from three study areas in New Mexico in 1982 and 1983.

\begin{tabular}{|c|c|c|c|c|}
\hline \multirow[b]{2}{*}{ Site $^{l}$} & \multirow[b]{2}{*}{ Treatment } & \multirow[b]{2}{*}{ Strata } & \multicolumn{2}{|c|}{ Sediment } \\
\hline & & & 1982 & 1983 \\
\hline & & & $\ldots \mathrm{kg}$ & /hr-_-_. \\
\hline \multirow[t]{3}{*}{$\begin{array}{l}\text { Bloomfield } \\
(363 a, 708 c)\end{array}$} & $\begin{array}{l}2,4-D \\
(282 a, 410 a)\end{array}$ & $\begin{array}{l}\text { Canopy } \\
\text { Interspace }\end{array}$ & $\begin{array}{l}201 a \\
363 a\end{array}$ & $\begin{array}{l}264 a \\
556 a b\end{array}$ \\
\hline & $\begin{array}{l}\text { Tebuthiuron } \\
\text { (326a, 1036bc) }\end{array}$ & $\begin{array}{l}\text { Canopy } \\
\text { Interspace }\end{array}$ & $\begin{array}{l}308 a \\
344 a\end{array}$ & $\begin{array}{l}903 b c \\
1169 c\end{array}$ \\
\hline & $\begin{array}{l}\text { Control } \\
(483 a, 893 b)\end{array}$ & $\begin{array}{l}\text { Canopy } \\
\text { Interspace }\end{array}$ & $\begin{array}{l}267 \mathrm{a} \\
699 \mathrm{ab}\end{array}$ & $\begin{array}{l}627 a b \\
1159 c\end{array}$ \\
\hline \multirow[t]{3}{*}{$\begin{array}{l}\text { Gobernador } \\
\text { (504b, 1049d) }\end{array}$} & $\begin{array}{l}2,4-D \\
(291,1031 b c)\end{array}$ & $\begin{array}{l}\text { Canopy } \\
\text { Interspace }\end{array}$ & $\begin{array}{l}271 a \\
312 a\end{array}$ & $\begin{array}{l}962 \mathrm{ab} \\
1101 \mathrm{~b}\end{array}$ \\
\hline & $\begin{array}{l}\text { Tebuthiuron } \\
\text { (747ab, 134Ic) }\end{array}$ & $\begin{array}{l}\text { Canopy } \\
\text { Interspace }\end{array}$ & $\begin{array}{l}759 b \\
735 b\end{array}$ & $\begin{array}{l}1309 b \\
1375 b\end{array}$ \\
\hline & $\begin{array}{l}\text { Control } \\
(475 a, 775 b)\end{array}$ & $\begin{array}{l}\text { Canopy } \\
\text { Interspace }\end{array}$ & $\begin{array}{l}381 \mathrm{a} \\
569 \mathrm{ab}\end{array}$ & $\begin{array}{r}527 \mathrm{a} \\
1022 \mathrm{~b}\end{array}$ \\
\hline \multirow[t]{3}{*}{$\begin{array}{l}\text { Aztec } \\
\text { (545b, 1326d) }\end{array}$} & $\begin{array}{l}2,4-\mathrm{D} \\
(596 \mathrm{ab}, 1262 \mathrm{c})\end{array}$ & $\begin{array}{l}\text { Canopy } \\
\text { Interspace }\end{array}$ & $\begin{array}{l}609 \mathrm{ab} \\
582 \mathrm{ab}\end{array}$ & $\begin{array}{l}863 a \\
1662 a b\end{array}$ \\
\hline & $\begin{array}{l}\text { Tebuthiuron } \\
\text { (595ab, 1421c) }\end{array}$ & $\begin{array}{l}\text { Canopy } \\
\text { Interspace }\end{array}$ & $\begin{array}{l}352 a \\
838 b\end{array}$ & $\begin{array}{r}895 a \\
1947 b\end{array}$ \\
\hline & $\begin{array}{l}\text { Control } \\
(446 a, 1295 c)\end{array}$ & $\begin{array}{l}\text { Canopy } \\
\text { Interspace }\end{array}$ & $\begin{array}{l}377 a \\
515 a b\end{array}$ & $\begin{array}{r}655 a \\
1934 b\end{array}$ \\
\hline
\end{tabular}

'Means under a site and treatment correspond to data collected in 1982 and 1983 , respectively.

${ }^{2}$ Means under a column heading and within a study site followed by the same letter are not significantly different at the 0.05 probability level.

that if short-term differences in watershed conditions between herbicide treated and untreated rangeland occurs, then changes will probably be greatest in the canopy zone. In contrast, an increase in infiltration and a reduction of erosion in the interspace may be a benefit of sagebrush control only in the long term.

\section{Literature Cited}

Balliette, J.F. 1984. Evaluation of range improvement following chemical control of big sagebrush in northern New Mexico. M.S. thesis. New Mexico State University, Las Cruces.

Berry, C.R., Jr. 1979. Impact of sagebrush management on riparian and stream habitat. p. 192-209. In: Sagebrush Ecosystem: A Symposium, April 1978, Coll. Natur. Resour., Utah State Univ., Logan.

Blackburn, W.H. 1973. Infiltration rate and sediment production of selected plant communities and soils in five rangelands in Nevada. Ph.D. Diss. Univ. of Nevada, Reno.

Blackburn, W.H. 1975. Factors influencing infiltration and sediment production of semiarid rangelands in Nevada. Water Res. Res. 11:929-937.
Blackburn, W.H. 1984. Influence of brush control on hydrologic characteristics of range watersheds. Proc.-Brush Manage. Symp., Albuquerque, New Mexico.

Blackburn, W.H., R.O. Meewig, and C.M. Skau. 1974. A mobile infiltrometer for use on rangeland. J. Range Manage. 27:322-323.

Blackburn, W.H., and C.M. Skau. 1974. Infiltration rates and sediment production of selected plant communities in Nevada. J. Range Manage. 27:476-479.

Blake, C.A. 1965. Methods of soil analysis. Amer. Soc. Agron. Series No. 9. Madison, Wis.

Bouyoucos, G.J. 1962. Hydrometer method improved for making particle size analysis of soil. Agron. J. 54:464-465.

Britton, C.M., and F.A. Sneva. 1984. Big sagebrush control with tebuthiuron. J. Range Manage. 36:707-708.

Brock, J.W., W.H. Blackburn, and R.H. Hass. 1982. Infiltration and sediment production on a deep hardland range site in northcentral Texas. J. Range Manage. 35:195-198.

Dixon, R.M. 1978. Water infiltration control on rangelands: principles and practices. In: Proceedings, First International Rangeland Congress, Soc. Range Manage.

Dunne, T., and L.B. Leopold. 1978. Water in environmental planning. W.H. Freeman and Co., San Francisco.

Elwell, H.M., and M.B. Cox.1950. New methods of brush control for more growth. J. Range Manage. 3:46-51.

Evans, R.A., J.A. Young, and R.E. Eckert, Jr. 1979. Use of herbicides as a management tool. p. 110-116. In: Sagebrush Ecosystem: A Symposium, April 1978, Coll. Natur. Resour., Utah State Univ., Logan.

Gifford, G.F., and R.H. Hawkins. 1976. Grazing systems and watershed management: A look at the records. J. Soil and Water Conservation. 31:281-283.

Hull, A.C., Jr., and W.T. Vaughn. 1951. Controlling big sagebrush with 2,4-D and other chemicals. J. Range Manage. 4:158-164.

Hyder, D.N. 1953. Controlling big sagebrush with growth regulators. J. Range Manage. 6:109-116.

Kincaid, and Williams. 1966. Rainfall effects on soil surface characteristics following range improvement treatments. J. Range Manage. 19:346-351.

McDaniel, K.C., and J.F. Balliette. 1984. Control of sagebrush (Artemesia tridentata) with pelleted tebuthiuron. In Press. Weed Sci.

McDaniel, K.C., and G.L. Garrison. 1982. New Mexico brush inventory. New Mexico Dep. Agr., Spec. Report No. 1.

Melton, F.A. 1940. A tentative classification of sand dunes, its application to dune history in southern high plains. J. Geol. 48:113-174.

Rosa, J.M., and M.H. Tigerman. 1951. Some methods for relating sediment production to watershed condition. U.S. Forest Service, Intermtn. Forest and Range Exp. Sta., Res. Paper 26.

Scifres, C.J. 1980. Brush management. Principles and practices for Texas and the southwest. Texas A\&M Univ. Press. College Station, Texas.

Steel, R.G.D., and J.H. Torrie. 1960. Principles and procedures of statistics. McGraw-Hill Book Co., Inc., New York.

Satterlund, D.R. 1972. Wildland watershed management. John Wiley and Sons, New York.

Tisdale, E.W., M. Hironaka, and M.A. Fosberg. 1969. The sagebrush region of Idaho. Agr. Exp. Sta., Univ. of Idaho. Bull. 512.

USDA, SCS. 1982. Soil survey of Taos County and parts of Rio Arriba and Mora Counties New Mexico. U.S. Dep. Agr. Soils Cons. Serv.

Whitson, T.D., and T.P. Alley. 1984. Tebuthiuron effects of Artemisia spp. and associated grasses. Weed Sci. 32:180-184.

Young, J.A., R.A. Evans, and R.E. Eckert, Jr. 1980. Successional patterns and productivity potentials of the sagebrush and salt desert ecosystems. In: National Science Foundation, Bureau of Land Manage., Symposium, Las Vegas, Nev. 